\title{
Análise da Ambiguidade Discursiva em uma Cooperativa Popular na Economia Solidária - Brasil - 2000/2010
}

\author{
Simone Aparecida Lisniowski \\ Orientador: Prof ${ }^{a}$. Dra. Christiane Girard Ferreira Nunes \\ Curso: Doutorado em Sociologia \\ Data da Defesa: 16.12.10
}

$\mathrm{E}$ sta pesquisa se propôs a analisar a ambiguidade na vida coletiva de uma cooperativa popular, identificando suas manifestações discursivas no processo de integração e indiferenciação de sentidos em torno das interações entre seus membros, na busca de realização da proposta do grupo. A pesquisa buscou desenvolver um método empírico de análise da ambiguidade por meio de uma coleta de dados apoiada na narrativa da história de vida, com entrevistas individuais e em grupo, gravadas e degravadas, de 9 (nove) membros de uma cooperativa popular, 4 (quatro) membros da equipe da incubadora responsável pelo processo de formação e assessoramento da cooperativa pesquisada e 2 (dois) ex-integrantes da equipe da incubadora. A interpretação dos dados foi dividida em três etapas: análise semântica dos termos ambíguos; análise do discurso (Fairclough); e análise de conteúdo para categorização das ambiguidades apoiadas na literatura em Economia Solidária, em Simmel e na Sociologia Clínica. A análise do discurso possibilitou definir categorias para compreensão da ambiguidade como manifestação discursiva dos processos de interação grupal na busca de integração das multiplicidades e indiferenciação de sentidos (Simmel, Bleger) no processo de formação de uma cooperativa, resultando em três diferentes dimensões de manifestação: 1) psicossocial; 2) sócio-organizacional e; 3) sociopolítica. A partir da análise semântica foram definidas as dinâmicas da ambiguidade na linguagem, nesse processo de integração e indiferenciação: 1) a condensação de sentidos em um único termo; 2) o deslocamento de sentidos de outros contextos para o contexto da Economia Solidária; e 3) a sobreposição de sentidos que, em momentos de conflitos, foram dicotomizadas e sofreram oscilações de sentidos. A ambiguidade, como modo de integração de sentidos e indiferenciação das diferenças, se manifestou na interação grupal como forma de: 1) abrandar os conflitos, deixando-os latentes e implícitos no discurso; 2) manter práticas consideradas mais eficazes que se mantinham apoiadas em pressupostos heterogestionários; 3) transformar sentidos, diluindo seus significados anteriores e possibilitando a presença de novos sentidos 
no grupo; 4) encobrir intenções, objetivos e sentidos quando estes se revelam contrários à proposta do cooperativismo; 5) manifestar sentimentos, vontades e pensamentos ambivalentes. A ambiguidade possibilita um espaço propício, quando não indispensável, à elaboração dos sentidos subjacentes aos processos de conflito e de transição que convivem na proposta da Economia Solidária. Os impactos da ambiguidade no grupo revelam a importância da construção de espaços democráticos, de participação coletiva e do desenvolvimento de práticas autogestionárias, para que seus sujeitos encontrem espaço de explicitação e negociação das diferenças.

Palavras-chave: economia solidária; cooperativa popular; ambiguidade discursiva; práticas autogestionárias; integração e indiferenciação de sentidos. 